Volume 1 Nomor 22021

http://journal.febubhara-sby.org/bharanomics

ISSN (Online): 2774-7190

Eharanomics

\title{
Pengaruh Tingkat Inflasi, Kurs IDR, CAR dan Dana Pihak Ketiga terhadap Profitabilitas Perbankan Syariah di Indonesia Periode 2013-2017
}

\author{
*Rekha Dwi Puspita Rini, Mohammad Balafif, Nurul Imamah \\ Fakultas Ekonomi dan Bisnis, Universitas Bhayangkara Surabaya, Indonesia
}

DOI: 10.46821/bharanomics.v1i2.159

\begin{abstract}
Abstrak
Penelitian ini bertujuan untuk menganalisis apakah Tingkat Inflasi, Kurs IDR, CAR dan Dana Pihak Ketiga berpengaruh secara simultan terhadap Profitabilitas (ROA) Perbankan Syariah di Indonesia Periode 2013-2017, serta menganalisis apakah Tingkat Inflasi, Kurs IDR, CAR dan Dana Pihak Ketiga berpengaruh secara parsial terhadap Profitabilitas (ROA) Perbankan Syariah di Indonesia Periode 2013-2017 dan untuk menganalisis variabel independen mana yang berpengaruh paling dominan terhadap profitabilitas (ROA). Penelitian ini menggunakan metode kuantitatif dengan model analisis regresi linier berganda. Adapun sumber data yang digunakan adalah data sekunder yang dipublikasikan oleh Otoritas Jasa Keuangan dan Bank Indonesia. Berdasarkan analisa data yang dilakukan, diperoleh kesimpulan bahwa secara simultan variabel dependen (ROA) dapat dijelaskan oleh variabel independen yang terdiri dari Tingkat Inflasi, Kurs IDR, CAR dan DPK. Secara parsial variabel Kurs IDR dan CAR berpengaruh negatif terhadap ROA. Sementara variabel Tingkat Inflasi dan DPK tidak berpengaruh terhadap ROA.
\end{abstract}

Kata kunci: Tingkat Inflasi, Kurs IDR, CAR, DPK, Profitabilitas, ROA

\begin{abstract}
:
This study aims to analyze whether the Inflation Rate, IDR Exchange Rate, CAR and Third Party Funds simultaneously influence the Profitability (ROA) of Islamic Banking in Indonesia for the 2013-2017 Period, as well as to analyze whether the Inflation Rate, IDR Exchange Rate, CAR and Third Party Funds have an effect partial to the Profitability (ROA) of Islamic Banking in Indonesia for the 2013-2017 period and to analyze which independent variable has the most dominant influence on profitability (ROA). This study uses quantitative methods with multiple linear regression analysis models. The data source used is secondary data published by the Financial Services Authority and Bank Indonesia. Based on the data analysis, it is concluded that simultaneously the dependent variable (ROA) can be explained by the independent variable consisting of the inflation rate, the IDR exchange rate, CAR and TPF. Partially the IDR exchange rate and CAR variables have a negative effect on ROA. Meanwhile, the inflation rate and TPF variables had no effect on ROA.
\end{abstract}

Keywords: Inflation Rate, IDR Exchange Rate, CAR, TPF, Profitability, ROA

\section{PENDAHULUAN}

Perkembangan perekonomian di Indonesia saat ini sudah mengalami peningkatan yang cukup signifikan. Salah satunya adalah uang, uang memainkan peranan yang sangat penting bagi semua aspek kegiatan masyarakat. Uang merupakan suatu kebutuhan, bahkan uang menjadi salah satu penentu stabilitas dan kemajuan perekonomian di suatu negara (Kasmir, 2014). Dalam hal ini, maka peranan lembaga keuangan terutama bank sangatlah besar.

*Corresponding Author:

Hal: $104-113$

Email: rekalee12@gmail.com 
Indonesia merupakan negara yang mayoritas penduduknya beragama Islam, sehingga masyarakat mengharapkan kehadiran sistem lembaga keuangan yang tidak hanya mementingkan kebutuhan finansial saja namun juga memenuhi kebutuhan moralitasnya. Hal ini menjadi salah satu dasar terbentuknya Perbankan Syariah di Indonesia. Perbankan syariah senantiasa mengalami pertumbuhan yang cukup pesat dari berbagai aspek, Secara kelembagaan, jaringan perbankan syariah meningkat menjadi 11 BUS dengan total jaringan kantor mencapai 1.688 kantor dan 1.277 office channeling (Publikasi Bank Indonesia). Kemudian tahun 2018 berkembang menjadi 13 BUS dan 21 UUS (Unit Usaha Syariah), dengan total jaringan Kantor Pusat mencapai 724 dan Kantor Cabang Pembantu sebanyak 1.315 serta Kantor Kas mencapai 404 (Statistik Perbankan Syariah, Februari 2017). Tumbuh dan berkembangnya lembaga keuangan bank dalam perekonomian sangat ditentukan oleh besarnya tingkat keuntungan yang diperoleh dalam kegiatan operasionalnya. Indikator yang digunakan untuk mengukur tingkat profitabilitas suatu bank salah satunya adalah Return On Assets (ROA). ROA penting bagi bank karena digunakan untuk mengukur efektifitas perusahan dalam menghasilkan keuntungan dalam memanfaatkan aktiva yang dimilikinya (Hidayati, 2014).

Peningkatan tingkat keuntungan yang tinggi bagi bank dapat dipengaruhi oleh beberapa faktor, baik faktor internal ataupun faktor eksternal. Faktor internal merupakan faktor mikro atau faktor spesifik bank yang menentukan profitabilitasnya. Sedangkan faktor eksternal terkait dengan kondisi makroekonomi dalam kegiatan bisnis bank syariah diantaranya meliputi tingkat inflasi dan kurs. Faktor lain yang mempengaruhi profitabilitas bank umum syariah adalah faktor internal dari dalam bank yaitu CAR atau Capital Adquacy Ratio. Semakin tinggi CAR maka semakin baik kemampuan bank tersebut untuk menanggung risiko dari setiap aktiva produktif yang berisiko. Faktor internal lain yang mempengaruhi profitabilitas bank syariah adalah Dana Pihak Ketiga atau DPK. DPK merupakan dana yang dihimpun dari masyarakat dalam bentuk giro, tabungan dan deposito yang kemudian disalurkan kembali kepada masyarakat melalui pembiayaan sehingga bank dapat menghasilkan profit (Ginting, 2014). Oleh karena itu bank syariah harus selalu memastikan keadaan likuiditas perbankannya bergerak kearah positif. Berikut adalah data perkembangan DPK Bank Umum Syariah di Indonesia.

Sesuai latar belakang yang telah dibahas di atas, maka dapat dirumuskan beberapa permasalahan dalam penelitian ini yaitu: Apakah tingkat inflasi, kurs IDR, CAR dan DPK secara simultan berpengaruh positif dan signifikan terhadap profitabilitas perbankan syariah. Apakah tingkat inflasi, kurs IDR, CAR dan DPK secara parsial berpengaruh positif dan signifikan terhadap profitabilitas perbankan syariah. Manakah dari tingkat inflasi, kurs IDR, CAR dan DPK yang berpengaruh dominan terhadap profitabilitas perbankan syariah.

\section{TINJAUAN PUSTAKA Profitabilitas}

Sartono (2010:122) menyatakan bahwa profitabilitas adalah kemampuan perusahaan memperoleh laba dalam hubungannya dengan penjualan, total aktiva maupun modal sendiri. Pada penelitian ini penulis akan menghitung tingkat profitabilitas dengan 


\section{Bharanomics}

Vol. 1 No. 22021

Rekha D. P. Rini dkk., Profitabilitas Perbankan Syariah di Indonesia

menggunakan tolak ukur Return On Asset (ROA) menurut Kasmir (2013:201) pengertian ROA adalah : "Rasio yang menunjukan hasil (return) atas jumlah aktiva yang digunakan dalam perusahaan. Selain itu, ROA memberikan ukuran yang lebih baik atas profitabilitas perusahaan karena menunjukan efektivitas manajemen dalam menggunakan aktiva untuk memperoleh pendapatan." Rumus dari Return On Asset (ROA) menurut Kasmir (2013:199), adalah sebagai berikut :

ROA $=$ Laba Setelah Pajak $\times 100 \%$

Total Aset

\section{Inflasi}

Inflasi adalah proses kenaikan harga-harga umum barang-barang secara terusmenerus (Nopirin, 2007:25). Kenaikan harga dari satu atau dua macam barang saja tidak dapat dikatakan sebagai inflasi kecuali kenaikan tersebut membawa dampak terhadap kenaikan harga sebagian besar barang-barang lain.

Dalam penggolongannya inflasi dibedakan menjadi empat macam, yaitu sebagai berikut (Boediono, 2002) :
a. Inflasi Ringan : $<10 \%$ per tahun
b. Inflasi Sedang : $10-30 \%$ per tahun
c. Inflasi Berat : 30-100\% per tahun
d. Hiperinflasi : $>100 \%$ per tahun

Untuk menentukannya perlu diperhatikan data indeks harga konsumen dari satu periode tertentu dan seterusnya dibandingkan dengan indeks harga pada periode sebelumnya.

\section{Kurs IDR}

Kurs adalah nilai tukar suatu mata uang dengan mata uang lainnya, kurs atau nilai tukar biasanya digunakan dalam transaksi yang melibatkan dua negara atau lebih. Pengertian kurs atau nilai tukar lainnya seperti yang dikemukakan oleh Ekananda (2014:168). Kurs merupakan harga suatu mata uang relatif terhadap mata uang negara lain. Kurs memainkan peranan penting dalam keputusan-keputusan pembelanjaan, karena kurs memungkinkan kita menerjemahkan harga- harga dari berbagai negara ke dalam satu bahasa yang sama.

Didalam menentukan suatu kurs di suatu negara, sejatinya terdapat beberapa sistem yang dipakai suatu negara dalam menentukan nilai kursnya. Menurut Ekananda (2014:314) terdapat 5 (lima) sistem kurs valuta asing yang dipakai suatu negara, yaitu:

a. Sistem kurs bebas (floating) Dalam sistem ini tidak ada campur tangan pemerintah untuk menstabilkan nilai kurs. Nilai tukar kurs ditentukan oleh permintaan dan penawaran terhadap valuta asing.

b. Sistem kurs tetap (fixed) Dalam sistem ini pemerintah atau bank sentral negara yang bersangkutan turut campur secara aktif dalam pasar valuta asing dengan membeli atau menjual valuta asing jika nilainya menyimpang dari standar yang telah ditentukan. 


\section{Bharanomics}

Vol. 1 No. 22021

Rekha D. P. Rini dkk., Profitabilitas Perbankan Syariah di Indonesia

c. Sistem kurs terkontrol atau terkendali (controlled) Dalam sistem ini pemerintah atau bank sentral negara yang bersangkutan mempunyai kekuasaan eksklusif dalam menentukan alokasi dari penggunaan valuta asing yang tersedia.

d. Sistem Crawling Peg Otoritas moneter dalam sistem ini mengaitkan mata uang domestik dengan beberapa mata uang asing. Nilai tukar tersebut secara periodik dirubah secara berangsur-angsur dalam persentase yang kecil. Sistem ini di pakai di Indonesia pada periode 1988-1995.

e. Sistem Ajustable Peg dalam sistem ini otoritas moneter selain berkomitmen untuk mempertahankan nilai tukar juga berhak untuk merubah nilai tukar apabila terjadi perubahan dalam kebijakan ekonomi.

\section{Capital Adequacy Ratio (CAR)}

Capital Adequacy Ratio (CAR) merupakan rasio permodalan yang menunjukkan kemampuan bank dalam menyediakan dana untuk keperluan pengembangan usaha dan menampung risiko kerugian dana yang diakibatkan oleh kegiatan bank. Dengan kata lain, Capital Adequacy Ratio adalah rasio kinerja bank untuk mengukur kecukupan modal yang dimiliki bank untuk menunjang aktiva yang mengandung atau menghasilkan resiko. (Nusantara, 2009).

Rasio ini penting karena dengan menjaga CAR pada batas aman yaitu minimal 8\% berdasarkan ketentuan BI, berarti juga melindungi nasabah dan menjaga stabilitas sistem keuangan secara keseluruhan. Semakin besar nilai CAR mencerminkankemampuan perbankan yang semakin baik dalam menghadapi kemungkinan risiko kerugian dan memberikan kontribusi yang cukup besar bagi profitabilitas (Satrio,2012). Secara matematis CAR dapat dirumuskan sebagai berikut:

$\mathrm{CAR}=\frac{\text { Modal }}{\mathrm{ATMR}} \times 100 \%$

\section{Dana Pihak Ketiga}

Dana pihak ketiga berdasarkan UU Perbankan No. 10 tahun 1998 adalah dana yang dipercayakan oleh masyarakat kepada bank berdasarkan perjanjian penyimpanan dana dalam bentuk giro, deposito, sertifikat deposito, tabungan, dan bentuk lainnya (Rivai, 2007).

Menurut UU No. 21 Tahun 2008 tentang perbankan syariah (Pasal 1) disebutkan bahwa, "Simpanan adalah dana yang dipercayakan oleh Nasabah kepada Bank Syariah dan/atau UUS berdasarkan Akad wadi'ah atau Akad lain yang tidak bertentangan dengan Prinsip Syariah dalam bentuk Giro, Tabungan, atau bentuk lainnya yang dipersamakan dengan itu". secara matematis DPK dapat dirumuskan sebagai berikut:

DPK $=$ Giro + Tabungan + Deposito 
Bharanomics

Vol. 1 No. 22021

Rekha D. P. Rini dkk., Profitabilitas Perbankan Syariah di Indonesia

\section{METODE PENELITIAN}

Metode yang digunakan dalam penelitian ini adalah metode kuantitatif. Penelitian ini dilakukan untuk menguji bagaimana pengaruh variabel Tingkat Inflasi, Kurs IDR, CAR dan DPK berpengaruh terhadap Profitabilitas Perbankan Syariah di Indonesia serta mengukur seberapa besar pengaruh tersebut apabila ada.

Adapun populasi yang digunakan dalam peneltian ini adalah seluruh Perbankan Syariah yang terdapat di Indonesia. Jumlah keseluruhan bank syariah yang ada adalah 198 bank yang meliputi 13 BUS, 21 UUS dan 164 BPRS yang mengeluarkan laporan keuangan periode 2013-2017. Pengambilan sampel pada penelitian ini dilakukan secara purposive sampling atau judgement sampling yaitu Bank Umum Syariah (BUS) di Indonesia yang telah memenuhi kriteria sampel. Kriteria tersebut antara lain :

a. Bank Umum Syariah yang terdaftar di Bank Indonesia pada tahun periode 20132017 dengan jumlah keseluruhan bank sebanyak 13 bank.

b. Bank Umum Syariah yang melaporkan laporan keuangannya secara lengkap selama tahun 2013- 2017 yang dipublikasikan menjadi satu dalam Statistik Perbankan Syariah oleh situs resmi OJK.

c. Tersedia laporan keuangan bulanan pada periode waktu penelitian.

d. Memiliki kelengkapan data CAR dan DPK selama periode penelitian.

Untuk menjawab pertanyaan penelitian mengenai faktor-faktor apa yang mempengaruhi profitabilitas perbankan syariah dan untuk mendapatkan besaran pengaruh masing-masing faktor tersebut, dibentuk suatu model dengan menggunakan Regresi Linier Berganda Kemudian untuk pengujiannya dilakukan dengan uji asumsi klasik, koefisien determinasi dan uji hipotesis melalui program SPSS 25.0.

\section{HASIL DAN PEMBAHASAN}

Hasil pengujian uji asumsi klasik dilakukan terlebih dahulu sebelum dilakukan pengujian terhadap hipotesis penelitian. Pengujian ini dimaksudkan untuk mengetahui apakah model yang diajukan dalam penelitian ini dinyatakan lolos dari penyimpangan asumsi klasik. Uji asumsi klasik meliputi uji normalitas, uji multikolinearitas, uji heteroskedastisitas dan uji autokorelasi. Uji normalitas data menggunakan SPSS kolmogrov smirnov yang dapat dilihat dari tabel dibawah ini:.

Berdasarkan tabel 1, menunjukkan nilai probabilitas Asymp. Sig.(2-tailed) hitung adalah sebesar 0.200 atau $>0,05$. Maka dapat ditarik kesimpulan bahwa datadata dalam penelitian ini berdistribusi normal. Kemudian untuk uji multikolinearitas dapat diperoleh dari nilai VIF (Variance Inflation Factor) yang dapat dilihat dari tabel 2.

Tabel 1

Hasil Uji Normalitas

\begin{tabular}{ll}
\hline $\mathrm{N}$ & 60 \\
\hline Asymp. Sig. (2-tailed) & .200 \\
\hline
\end{tabular}

Sumber: Output SPSS (Data diolah), 2020 
Tabel 2

Hasil Uji Multikolinieritas

Coefficients $^{\mathrm{a}}$

\begin{tabular}{clcc}
\hline \multirow{2}{*}{ Model } & & & Collinearity Statistics \\
\cline { 3 - 4 } & & Tolerance & VIF \\
\hline \multirow{2}{*}{1} & Inflasi & .725 & 1.380 \\
& Kurs IDR & .761 & 1.314 \\
& CAR & .516 & 1.936 \\
& DPK & .439 & 2.276 \\
\hline
\end{tabular}

a. Dependent Variable: ROA

Sumber: Output SPSS (Data Diolah), 2020

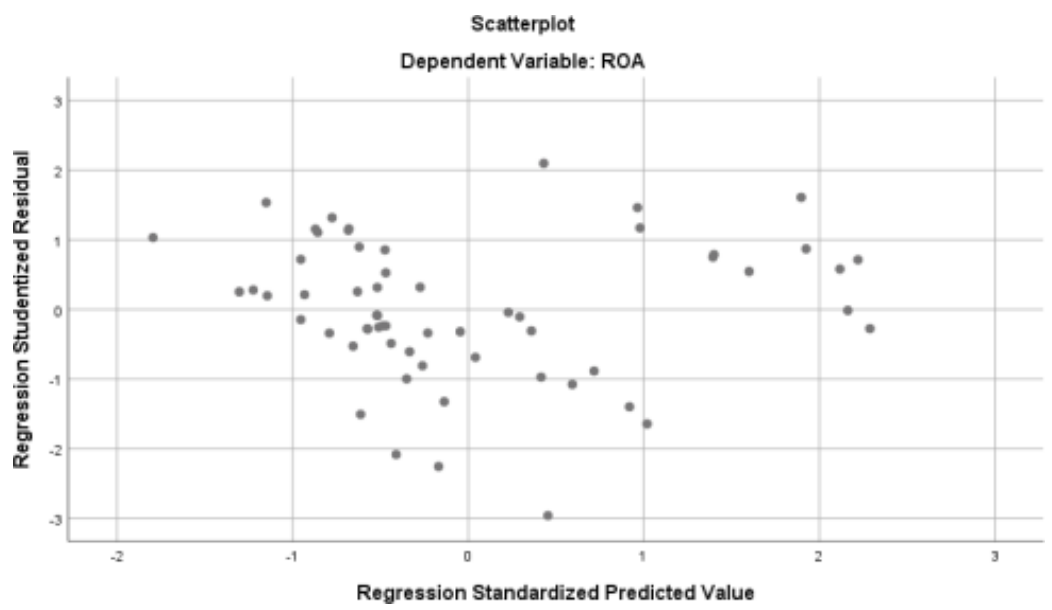

Sumber: Data Diolah, 2020

Gambar 1

\section{Uji Heteroskedastisitas}

Berdasarkan tabel 2, dapat dilihat masing-masing antar variabel bebas memiliki nilai VIF < 10. Dengan demikian dapat ditarik kesimpulan bahwa data dalam penelitian ini tidak terjadi masalah multikolinearitas.

Untuk uji heteroskedastisitas dapat dilihat dari grafik scatter plot antara variabel terikat (ZPRED) dengan residualnya (SRESID), dimana sumbu $\mathrm{x}$ adalah yang diprediksi dan sumbu y adalah residual. Menurut Ghozalli (2016) dasar pengambilan keputusan yang diambil sebagai berikut :

a. Jika pola tertentu seperti titik- titik yang dan membentuk suatu pola yang teratur (bergelombang, melebar, kemudian menyempit) maka telah terjadi Heteroskedastisitas.

b. Jika tidak ada pola yang jelas dan titik-titik menyebar diatas dan dibawah angka nol pada sumbu y maka tidak terjadi Heteroskedastisitas.

Berdasarkan pada Gambar 1. tidak terjadi heteroskedastisitas karena tidak ada pola yang jelas dan titik-titik menyebar diatas dan dibawah angka nol pada sumbu y. Sedangkan untuk uji autokorelasi dapat dilihat dari nilai Durbin Watson. Dengan ketentuan nilai hasil $-2>\mathrm{DW}<2$. 
Tabel 3

Uji Autokorelasi

Model Summary ${ }^{\mathbf{b}}$

\begin{tabular}{lccccc}
\hline Model & R & R Square & $\begin{array}{c}\text { Adjusted } \\
\text { RSquare }\end{array}$ & $\begin{array}{c}\text { Std. Error of the } \\
\text { Estimate }\end{array}$ & Durbin- Watson \\
\hline 1 & $.806^{\mathrm{a}}$ & .650 & .624 & .38114 & .774 \\
\hline
\end{tabular}

a. Predictors: (Constant), DPK, Kurs IDR, Inflasi, CAR

b. Dependent Variable: ROA

Sumber: Output SPSS (Data Diolah), 2020

Berdasarkan Tabel 3. diatas maka dapat disimpulkan bahwa tidak terjadi kasus autokorelasi pada data yang akan digunakan pada penelitian ini, karena dari nilai -2 $<$ Durbin- Watson $(\mathrm{dW})<2(-2<0,774<2)$.

Hasil uji regresi linear berganda menghasilkan persamaan sebagai berikut:

$\mathrm{Y}=7,498-0,026 \mathrm{X} 1-0,000407 \mathrm{X} 2-0,152 \mathrm{X} 3+0,000005902 \mathrm{X} 4$

Keterangan :

$\mathrm{Y}=\mathrm{ROA}$

$\mathrm{X} 1=$ Tingkat Inflasi X2 $=$ Kurs IDR

$\mathrm{X} 3=\mathrm{CAR}$

$\mathrm{X} 4=\mathrm{DPK}$

Berdasarkan persamaan regresi linier berganda diatas, maka dapat dijelaskan sebagai berikut:

a. Nilai konstanta ( $\beta 0)$ sebesar 7,498. dengan ini dapat diartikan bahwa ROA (Y) akan bernilai 7,498\% jika variabel inflasi (X1), kurs IDR (X2), CAR (X3), dan DPK (X4) masing-masing bernilai 0.

b. Nilai koefisien regresi $(\beta 1)$ untuk variabel inflasi $(X 1)$ sebesar - 0,026. Hal ini menunjukkan bahwa jika inflasi meningkat satu persen (1\%), maka nilai ROA akan turun sebesar $0,026 \%$ dengan asumsi variabel bebas lainnya dianggap konstan. Tanda negatif (tidak searah) menunjukkan pengaruh inflasi tidak searah terhadap ROA artinya terjadi hubungan negatif.

c. Nilai koefisien regresi ( $\beta 2)$ untuk variabel kurs IDR (X2) sebesar - 0,000407. Hal ini menunjukkan bahwa jika kurs IDR meningkat satu rupiah, maka nilai ROA akan mengalami penurunan sebesar 0,000407\% dengan asumsi variabel bebas lainnya dianggap konstan. Tanda negatif (tidak searah) menunjukkan pengaruh kurs IDR tidak searah terhadap ROA artinya terjadi hubungan negatif.

d. Nilai koefisien regresi ( $\beta 3$ ) untuk variabel CAR (X3) sebesar -0,152. Hal ini menunjukkan bahwa jika CAR meningkat satu persen, maka nilai ROA akan turun sebesar $0,152 \%$ dengan asumsi variabel bebas lainnya dianggap konstan. Tanda negatif (tidak searah) menunjukkan pengaruh CAR tidak searah terhadap ROA artinya terjadi hubungan negatif.

e. Nilai koefisien regresi ( $\beta 4$ ) untuk variabel DPK (X4) sebesar 0,000005902. Hal ini menunjukkan bahwa jika DPK meningkat satu miliyar rupiah, maka nilai ROA juga akan naik sebesar 0,000005902\% dengan asumsi variabel bebas lainnya dianggap konstan. Tanda positif (searah) menunjukkan pengaruh DPK searah terhadap ROA artinya terjadi hubungan positif. 
Tabel 4

Nilai Statistik Variabel

\begin{tabular}{ccc}
\hline Variabel & Sig. & Sig. \\
\hline X1 & 0,05 & .418 \\
X2 & 0,05 & .000 \\
X3 & 0,05 & .025 \\
X4 & 0,05 & .065 \\
\hline
\end{tabular}

Sumber: Data Diolah, 2020

Tabel 5

Tabel Koefisien Standarisasi

\begin{tabular}{lccc}
\hline & & \multicolumn{2}{c}{ Standardized Coefficients } \\
\cline { 2 - 4 } Model & Beta & $\mathrm{T}$ & Sig. \\
\hline 1 (Constant) & & 7.668 & .000 \\
Inflasi & -.077 & -.817 & .418 \\
Kurs IDR & -.834 & -9.117 & .000 \\
CAR & -.256 & -2.307 & .025 \\
DPK & .226 & 1.881 & .065 \\
\hline
\end{tabular}

a. Dependent Variable: ROA

Sumber: Data Diolah, 2020

Koefisien determinasi $\left(\mathrm{R}^{2}\right)$ bertujuan untuk mengukur seberapa jauh kemampuan model dapat menerangkan variasi variabel terikat. Nilai koefisien determinasi adalah antara 0 (nol) dan 1 (satu). Nilai Koefisien determinasi yang kecil berarti kemampuan variabel-variabel bebas dalam menjelaskan variasi variabel terikat amat terbatas. Nilai yang mendekati satu berarti variabel-variabel bebas memberikan hampir semua informasi yang dibutuhkan untuk memprediksi variasi variabel terikat. Hasil koefisien determinasi dapat dilihat dari besarnya $\mathrm{R}$ - square adalah 0.650 atau $65 \%$. Hal ini berarti $65 \%$ variabel terikat pertumbuhan aset dapat dijelaskan secara signifikan oleh variasi variabel bebas. Variabel bebas tersebut adalah Tingkat Inflasi, Kurs IR, CAR dan DPK sedangkan sisanya 35\% dipengaruhi ataudijelaskan oleh variabel lain yang tidak dijelaskan dalam penelitian ini. Pengujian hipotesis dilakukan dengan uji F (secara simultan), uji t (secara parsial) dan uji dominan.

Berdasarkan pada nilai Sig. $<0.05(0,000<0,05)$ maka H0 ditolak dan H1 diterima yang berarti bahwa variabel-variabel bebas (inflasi, kurs IDR, CAR, dan DPK) secara simultan berpengaruh signifikan terhadap variabel ROA.

a. Inflasi tidak berpengaruh terhadap ROA dengan nilai sig. $>0,05(0,418>0,05)$. Hal ini menunjukkan bahwa secara parsial inflasi tidak berpengaruh signifikan terhadap ROA.

b. Kurs IDR berpengaruh negatif terhadap ROA dengan nilai sig. $<0,05(0,000<$ 0,05). Hal ini menunjukkan bahwa secara parsial kurs IDR berpengaruh negatif dan signifikan terhadap ROA.

c. CAR berpengaruh negatif terhadap ROA dengan nilai sig. $<0,05(0,025<0,05)$. Hal ini menunjukkan bahwa secara parsial CAR berpengaruh negatif dan 


\section{Bharanomics}

Vol. 1 No. 22021

Rekha D. P. Rini dkk., Profitabilitas Perbankan Syariah di Indonesia

signifikan terhadap ROA.

d. DPK tidak berpengaruh terhadap ROA dengan nilai sig. $>0,05(0,065>0,05)$. Hal ini menunjukkan bahwa secara parsial DPK tidak berpengaruh signifikan terhadap ROA.

Berdasarkan tabel diatas maka dapat disimpulkan bahwa variabel yang paling dominan yang berpengaruh terhadap ROA adalah Kurs IDR hal ini dikarenakan Kurs IDR memiliki nilai koefisien tersandarisasi terbesar sebesar 0,834 atau $83,4 \%$ dari seluruh besarnya pengaruh.

\section{SIMPULAN}

Berdasarkan uraian analisis dan pembahasan pada bab sebelumnya, maka dapat disimpulkan sebagai berikut. Variabel bebas (Tingkat Inflasi, Kurs IDR, CAR, dan DPK) secara simultan atau bersama- sama berpengaruh signifikan terhadap variabel terikat (ROA). Variabel Tingkat Inflasi secara parsial tidak berpengaruh signifikan terhadap ROA, variabel Kurs IDR secara parsial berpengaruh negatif dan signifikan terhadap ROA, variabel CAR berpengaruh negatif dan signifikan terhadap ROA dan variabel DPK secara parsial tidak berpengaruh signifikan terhadap ROA. Variabel bebas yang paling berpengaruh terhadap variabel ROA adalah Kurs IDR dengan nilai koefisien standarisasi yang paling besar sebesar 0,834 atau 83,4\% dibandingkan dengan variabel independen lainnya yaitu tingkat inflasi, CAR, dan DPK.

\section{DAFTAR PUSTAKA}

Boediono, 2002, Ekonomi Makro: Seri Sinopsis Pengantar Ilmu Ekonomi No.1 Edisi 2, BPEE, Yogyakarta.

Ekananda, Mahyus, 2014, Ekonomi Internasional, Erlangga, Jakarta.

Ginting, 2014, Pengaruh DPK, NPF dan CAR Terhadap Profitabilitas Bank Umum Syariah (Studi Kasus pada Bank Syariah BUMN Periode 2010-2013), Skripsi S1, Universitas Islam Negeri Sultan Syarif Kasim Riau.

Hidayati, 2014, Pengaruh Inflasi, BI Rate, dan Kurs Terhadap Profitabilitas Bank Syariah Di Indonesia, IAIN Tulungagung, Tulungagung.

Kasmir, 2013, Analisis Laporan Keuangan, PT. Raja Grafindo Persada, Jakarta.

Kasmir, 2014, Bank dan Lembaga Keuangan Lainnya. Edisi Revisi, Cetakan Keempat belas, PT. Raja Grafindo Persada, Jakarta.

Nopirin, 2007, Ekonomi Moneter, Penerbit BPFE, Yogyakarta.

Nusantara, Ahmad Buyung, 2009, Analisis Pengaruh NPL, CAR, LDR, dan BOPO Terhadap Profitabilitas Bank", Tesis, Universitas Diponegoro, Semarang. 
Bharanomics

Vol. 1 No. 22021

Rekha D. P. Rini dkk., Profitabilitas Perbankan Syariah di Indonesia

Rivai, Veithzal, 2007, Bank and Financial Institute Management, PT.Raja Grafindo Persada, Jakarta.

Sartono, Agus 2010, Menejemen Keuangan Teori dan Aplikasi Edisi 4, BPFE Yogyakarta.

Satrio, Edhi Wibowo, 2012, Analisis Pengaruh Suku Bunga, Inflasi, CAR, BOPO,NPF Terhadap Profitabilitas Bank Syariah, Skripsi, Universitas Diponegoro, Semarang.

Suharyadi dan S.K. Purwanto, 2013, Statistika untuk Ekonomi dan Keuangan Modern, Edisi ke-2, Salemba Empat, Jakarta. 